\author{
Marijana Marelj ๑ https://orcid.org/0000-0001-5122-9938 \\ UiL OTS, Utrecht University
}

\title{
Timing is everything! On derivational complexity and multiple workspaces
}

\begin{abstract}
Under any derivational approach, syntactic computations proceed from more complex to less complex domains. Though such multiple workspaces get to be resolved into a single - matrix - workspace, the issue of timing-i.e. the point when multiple workspaces must resolve to a single derivational space has not been addressed in the literature. I argue that not only the direction, but also the timing of syntactic computations is guided by a more general requirement to reduce the computational complexity and I propose Multiple Workspaces Earliness Hypothesis to address this issue. On the empirical side, the technical apparatus and the analysis I propose allow me to capture the seemingly contradictory binding facts involving locative PPs as well as to treat adjuncts as relation, rather than absolute notions.
\end{abstract}

\section{Keywords}

adjuncthood, argumenthood, derivational complexity, multiple workspaces, nature of theta-roles, sideward movement

\section{Streszczenie}

W ramach każdej koncepcji derywacyjnej obliczenia składniowe przebiegają w kierun$\mathrm{ku}$ od domen bardziej do mniej złożonych. Mimo że takie równoległe pola derywacyjne zostają zredukowane do pojedynczego - głównego - pola, to kwestia czasu, tj. momentu, w którym poszczególne pola derywacyjne muszą ulec redukcji do jednej przestrzeni derywacyjnej, nie była dotąd przedmiotem badań w literaturze. Artykuł przedstawia argumenty za tym, że nie tylko kierunek, ale również rozplanowanie operacji składniowych w czasie determinowane są przez bardziej ogólny wymóg redukcji złożoności derywacyjnej. W tym celu sformułowana zostaje hipoteza o wczesności równoległych pól derywacyjnych. Z empirycznego punktu widzenia, aparat pojęciowy i analiza zaproponowana $\mathrm{z}$ artykule pozwalają na uchwycenie pozornie sprzecznych faktów dotyczących anaforycznego wiązania miejscownikowych fraz przyimkowych oraz na potraktowanie opcjonalnych składników frazowych jako relacji, a nie pojęć absolutnych.

\section{Słowa kluczowe}

status okolicznika, status argumentu, złożoność derywacyjna, równolegle pola derywacyjne, natura ról tematycznych, przesunięcie boczne 


\section{Introduction ${ }^{1}$}

Under a derivational approach (phase- and movement-based alike), syntactic computations proceed from syntactically more complex to syntactically less complex domains. In (1) \& (2), the embedded domain of the adjunct clause needs to be resolved before the matrix derivational space is activated. Technically, this is achieved via the Sideward Movement - SM (see Nunes 1995; Uriagareka 1999; Hornstein 2001; a.o) that allows Movement to take place from the adjunct clause - PP (Workspace 2) to the matrix $v \mathrm{P}$ (Workspace 1).

(1) a. Which paper ${ }_{i}$ did Mary file $t_{i}$ after John read $\mathrm{PG}_{\mathrm{i}}$

b. [[which paper $]_{\mathrm{i}} \operatorname{did}\left[_{\mathrm{TP}} \operatorname{Mary}_{\mathrm{T}}\left[_{\mathrm{vP}}\left[_{\mathrm{vP}} \text { Mary file [which paper }\right]_{\mathrm{i}}\right]_{\mathrm{PP}}\right.$ after John read [which paper] $\left.\left.\left.]_{i}\right]\right]\right]$ ]

(2) a. Mary filed her research paper before $\mathrm{PRO}_{\mathrm{i}}$ leaving Trans 10.

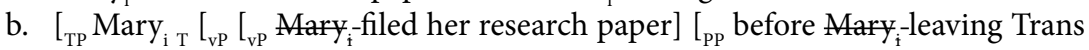
10]]]

Not only does SM deal elegantly with complex syntactic environments like the parasitic gaps (1) and adjunct control (2), but it also opens a possibility to treat adjuncts as relational, rather than as an absolute notion. This is empirically desirable since a given expression is only an adjunct in relation to another expression (3).

(3) a. Tristram put the book $\left[_{\mathrm{pp}}\right.$ on the table].

Argument

b. Tristram wrote the book $\left[_{\mathrm{PP}}\right.$ on the table $]$.

Adjunct

c. [In the Netherlands], doctors are well trained.

Adjunct

d. His doctor lives [in the Netherlands].

Argument

Despite its elegance and potential, there are serious issues that SM raises. Though the multiple workspaces get to be resolved into a single - matrix - workspace, the issue of timing-i.e. the point when multiple workspaces must resolve to a single derivational space has not been addressed in the literature. Clearly, SM cannot be allowed to apply "freely" since it would render (4) as grammatical:

(4) ${ }^{\star}$ Who did John laugh at Bill [before Mary spoke to whe]

Indeed, as argued by Hornstein, (4) crashes because two conflicting requirements need to be satisfied; "who" (base generated in PP) needs to wait until after $\mathrm{C}$ has entered the derivation before it can move, but the $\mathrm{PP}$ it is contained

\footnotetext{
${ }^{1}$ I would like to thank the two anonymous reviewers for their comments and suggestions. All errors remain my own.
} 
within needs to attach to the matrix structure before $\mathrm{T}$ has been merged. If (as nowadays standardly assumed) wh-movement proceeds via the edge of the $v \mathrm{P}$ phase, that creates an escape hatch for the $w h$-phase, rendering not only (4) as grammatical, but creating a general problem of massive overgeneration for SM.

To address these issues, I propose (5), itself guided by more general requirement to reduce the computational complexity.

(5) Multiple Workspaces Earliness Hypothesis

Multiple workspaces derivations must resolve to a single workspace at the earliest possible convenience, where "at the earliest possible convenience" means" "at the point when the adjunction site is created."

The paper is organized as follows. Section 2 presents the "binding puzzle" that the locative-PPs raise for argumenthood/adjuncthood as absolute notions. In Section 3, I discuss the technical machinery necessary to tackle the relevant data. Section 4 probes into the nature of thematic roles and it also discusses the motivation for the Sideward Movement. Section 5 provides a deeper insight into the issues of derivational complexity and the need and the way to restrict the SM. Section 6 concludes the paper.

\section{Puzzling behavior of PP-adjuncts}

Given the distributional similarities between the anaphor binding and NP-movement, it is unsurprising (though not uncontroversial) that the two have been argued to involve the same syntactic relation. ${ }^{2}$ One possibility to unify the two is given in Hornstein $(2001,2006)$, where the locality conditions of Principle A reduce to the locality conditions on movement and the interpretative properties of the dependency between the reflexive and its antecedent are derived syntactically. Adopting and adapting Hornstein's account, Marelj $(2008,2010)$ shows that the movement analysis captures the data in Serbo-Croatian (SC). If reflexivization is movement, it follows that sebe (elided in the second conjunct in (6)) is the reflex of the movement of Tristram and the only available reading is predicted to be the sloppy one. This prediction is borne out. Under a movement approach, the elimination of Principle A leads

\footnotetext{
${ }^{2}$ My intent here is not to argue that a derivational - movement - account is the only way to account for the distributional and interpretative properties of reflexives and bound pronouns. But given that Movement is an undeniable property of natural language and Binding Theory is not, the law of parsimony would favour the former over the latter type of analysis. Note, further, that Chomsky's (1986) revised BT links the antecedent and the reflexive derivationally, albeit through the covert (rather than the overt) movement of reflexive.
} 
to the elimination of Principle B, on empirical grounds: bound pronouns and reflexives are in complementary distribution $(7){ }^{3}$

(6) Lorens mrzi sebe, a i Tristram takodje.

Laurence hates himself, and Tristram does too.

(7) Tristram $_{i}$ kažnjava sebe $^{*}$ njega $_{i}$

Tristrami punishes himself/ $/$ him $_{\mathrm{i}}$

Movement derivation is not restricted to monoclausal environments like (7). Marelj (2010) gives evidence of movement in small clause environment (8a), infinitives (8b), and subjunctive da-complements (8c) of S-verbs of Progovac (Progovac 2005).

(8) a. $\mathrm{Svako}_{\mathrm{i}}$ smatra $\quad{ }_{\mathrm{SC}}$ sebe/njega $\mathrm{a}_{\mathrm{j} / \mathrm{i}}$ pamentim] everyone considers oneself smart.INST Everyone $_{i}$ considers oneself smart. $_{i}$

b. Svako želi [voleti sebe/njega $a_{j / \times}$ ] everyone want3.SG.PRES love.INF oneself

c. Svako želi [da voli sebe/njega $\mathrm{a}_{\mathrm{j} / \mathrm{i}}$ ] everyone want $3 . s \mathrm{sg}$ that love3.sG oneself Everyone wants to love oneself.

The first two are cross-linguistically well-known as restructuring - 'clause unification' environments and despite its morphological make up of a finite clause, such is the third one as well. In a series of works, Progovac (see Progovac 2005 and the references there) has shown that $d a$-complement clauses to verbs like želeti (want) are subjunctive-like in that they do not block clause-bound processes like clitic climbing and NPI licensing from taking place across clausal boundary.

Movement is barred in genuine bi-clausal domains. In such instances, as are the cases of extraction from the relative clause (9a) \& (9b) - sentential adjuncts, the Pronoun Insertion Strategy takes place and njega (9c) and him (9d) arise:

(9) a. ${ }^{*}$ Koji egzotični jezik je Lorens zaposlio mladu sekretaricu [koja govori __ ]?

b. ${ }^{*}$ Which exotic language did Laurence hire a young secretary [who speaks_]?

c. Luka ${ }_{\mathrm{i}}$ je zaljubljen u devojčicu [koja $(\mathbf{n j e}) \mathbf{g a}_{\mathrm{i}}{ }^{\star}{ }^{\star} \mathbf{s e}(\mathbf{b e})_{\mathrm{i}}$ hvali]

d. Luka is enamored with the girl [who praises him/*himself]

Since movement is standardly argued to be barred out of adjuncts in general (9) (sentential and non-sentential ones alike), the Pronoun Insertion Strategy

\footnotetext{
${ }^{3}$ Of course, throughout the discussion, the reader should not forget issues like the "accidental" coreferential reading for (7), noted and elaborated upon by Reinhart (1983) and discussed in many a work since.
} 
is expected in cases of locative PP-adjuncts as well. ${ }^{4}$ English data (11) seem to corroborate that. Standardly, himself in (11) is treated as a logophor in the sense of Reinhart and Reuland (see Reinhart and Reuland 1991, 1993). Unlike reflexives, logophors are permitted in environments where there is no local antecedent (11b). As reflexivization is restricted to co-arguments of a predicate, under a predicate-based account, the non-complementarity between himself and him is also expected. Under a movement account, logophors are not the result of movement and derivations in which they occur are not in competition with the Pronoun Insertion Strategy. Again, it follows that logophors are not in complementary distribution with pronouns. ${ }^{5}$

(10) a. ${ }^{\star}$ Who did you see the snake $\left[_{\mathrm{PP}}\right.$ near-whe]?

b. ??/*Pored čije je on video zmiju [Ppored čije noge] next.to whose AUx he seen snake next.towhose leg

(11) a. John saw a snake [ ${ }_{\text {PP-adjunct }}$ near himself/him]

b. Max boasted that the queen invited Mary and him/himself for tea.

Whereas SC (10b) suggests that the same kind of analysis should naturally extend to SC, the SC counterpart of (11a) challenges this kind of unity, under either a predicate-based or a movement theory. Namely, in (12), njega can only be referential and sebe is clearly a local reflexive (12).

(12) Jovan $_{\mathrm{i}}$ je video zmiju [pored sebe/ ${ }^{*}$ njega $_{\mathrm{i}}$ ]

John AUX see.PrT.M snake.ACC near oneself/him

Marelj (2018) argues that this (seemingly) misbehaving pieces of data (12) is hardly exceptional as different languages, e.g. German, Hindi, Latin and Hungarian, to name but a few, exhibit the same pattern of behavior. Further, based on the empirical evidence from Dutch, Marelj shows that the treatment of the relevant pronouns as logophor (as it would be predicted and is argued under either a movement or a predicate-based accounts) in cases that involve such locative PPs does not seem to be correct as she shows that the elements appearing in such PPs cannot be logophors. ${ }^{6}$

${ }^{4}$ The ban on extraction out of adjuncts is a standard assumption in syntactic theory, inspired by Ross (1967), firmly integrated as CED into the theory in Huang (1982), re-integrated in the minimalist framework in Uriagereka (1999) and further argued to hold universally (see Stepanov 2007, among others). There are (not fully understood) exceptions where extraction out of adjuncts is possible. The most well-studied exceptions are argued to be licensed by semantics (see Truswell 2011 for discussion and references). Such cases notwithstanding, crosslinguistically, for most speakers, extraction out of adjuncts is by and large unacceptable.

${ }^{5} \mathrm{SC}$ is a non-P stranding language but it allows the so-called extraordinary LBE (see Bošković 2008 and Talić 2013 and references there for a discussion, elaboration, and evidence that extraordinary LBE is truly movement).

${ }^{6}$ What seems to come out of the investigation is that, rather than SC, it is English that might seem as an "odd man out" in its behavior (10). But that is not the conclusion that Marelj (2018) 
Such a claim, however, leads us to an even more intriguing issue. Clearly, the near-PPs under consideration here are not complements of the relevant matrix verbs, in either SC or in English, in that that they receive the thematic role from the verbs in question. To solve this puzzle, Marelj (2018) proposes that binding into locative PP-adjuncts is yet another empirical instantiation of Sideward Movement. This allows her not only to account for the puzzle of the near- PPs, but also to probe into the nature of arguments and adjuncts and to capture the common denominator that the notions "arguments" and "adjuncts" have; the fact that neither of them is an absolute notion (recall examples in (3)).

\section{Adjuncts as a Relative Notion}

\subsection{Locative-PPs}

In the previous section, we have seen that locative PPs are adjuncts with respect to the matrix verb. However, for the purposes of binding, they seem to behave like complements. I have also argued that this controversial behavior can be resolved if we treat them as an instantiation of SM.

Allow me to illustrate how this works. For reasons of brevity, I will illustrate the point on SC/ENG, but bear in mind that this analysis extends to other languages as well (13):

(13) a. Jovan je video zmiju pored sebe.

b. John saw a snake near himself.

draws. She argues that English data like (10a) have perhaps been misanalysed. Among other things, she points out that it is not obvious that one can ever use a logophor in the locative PP headed by a locative preposition like near (i) to start with!

Mary claimed that the king saw his pet snake [near her/*herself]

Dutch offers an even clearer piece of evidence in favor of the non-logophoric status of the self-element inside of the PP in (i). Unlike English, where there is no morphological difference between the anaphor and the logophor, Dutch has the designated logophor with hemzelf/haarzelf morphologically distinct from the anaphor zichzelf (iia). The Dutch counterpart of (i) is given in (iib). Clearly, we are not dealing with logophors here.

(ii) a. Tristram/Marie zei dat ditboekgeschreven is [door Sue en hemzelf/haarzelf $/{ }^{*}$ zichzelf] Tristram/Mary said that this book written is [by Sue andhimself/herself/oneself] Tristram/Mary said that the book was written by Sue and himself-LOGOPHOR/herself-LOGOPHOR

b. Iedereen zag een slang naast [zich(zelf) $/{ }^{*}$ hemzelf $/{ }^{*}$ haarzelf] Everyone saw a snake near ANAPHOR/himselfLOGOPHOR/herselfLOGOPHOR Everyone saw a snake near himself-anaphor 
(14) a. $\left[{ }_{\mathrm{vp}}\right.$ saw a snake] Workspace 1

b. $\left[_{\mathrm{PP}}\right.$ near [Jovan]] Workspace 2

What follows is a sideward movement of Jovan from workspace 2 to 1 :

(15) $\left[_{\mathrm{vP}}[\right.$ Jovan] saw a snake] $\left[{ }_{\mathrm{PP}} \text { near [Jovan-SELF] }\right]^{7}$

Crucially, it is only now that the PP merges into the Workspace 1, thus becoming an adjunct. At this point, no movement out of the PP is possible anymore.

(16) $\left[_{\mathrm{vP}}\left[{ }_{\mathrm{vP}}[\right.\right.$ Jovan] saw a snake] $[$ ne nearfovan-SELF] $]$

The step in (15) is followed by the merger of matrix T, itself followed, in turn, by the movement of Jovan [Spec, TP]:

(17) $\left[_{\mathrm{TP}}\left[\right.\right.$ Jovan] $\mathrm{T}\left[_{\mathrm{vP}}\left[_{\mathrm{vP}}[\right.\right.$ Jovan $]$ saw a snake $]\left[_{\mathrm{PP}}\right.$ near Jovan $\left.\left.\left.-\mathrm{SELF}\right]\right]\right]$

The controversial adjunct/complement properties we have noted above can be accounted for and the derivation converges because the movement takes

${ }^{7}$ The role of SELF in (15) is to checks case (see Marelj 2008, 2010 regarding extensive discussion and references there). Since sebe/SELF is one of the ingredients in the derivation under consideration here, for convenience, I sum up the major points about its nature and its role. Sebe is a grammatical formative whose role is to check case. Whereas Jovan in (15) can acquire any number of $\theta$-roles (see discussion in $\$ 4$ please), it cannot check both locative and nominative. Sebe in (15) checks locative and Jovan nominative. SELF is a residue of movement; sebe in (15) is the "overt reflex" of the movement of Jovan. Sebe is a product of grammatical operation; it is not an item present in the numeration (see (25) in 4.2 please). This being the case, the $\phi$-features of SELF are predicted to be semantically intern. Since pronouns are bundles of $\phi$-features, the inertness means that the $\phi$-features of the SEBE do not contribute to the interpretation. Referential possessive pronouns, like mene (me) or nju (her) on the other hand, are a part of the lexical array, and their $\phi$-features must therefore remain semantically active and relevant to the interpretation. If the $\phi$-features of sebe are intert, it follows that (ia) can be contradicted by (ib). This prediction is borne out. As no semantically active material can be added in the course of the derivation (Inclusiveness Condition), the $\phi$-features of grammatical formatives must be semantically inert.

(i) a. Samo ja smatram sebe pamentom

Only I consider self smart

Only I consider myself smart

b. Nije tačno! Lorens smatra sebe pametnim a i Lucie smatra sebe pamentom. not right Laurence considers self smart and Lucie considers self smart That is not true. Laurence considers himself smart and Lucie considers herself smart.

In sum, the approach to referential pronouns here does not differ from standard B(inding) $\mathrm{T}$ (heory) approach. Under the movement account, referential pronouns are treated as elements that enter the derivation via the lexical insertion and whose $\phi$-features are relevant to the interpretation. The difference between the two approaches arises with respect to SELF elements (reflexives). Under the movement account, reflexives are treated as grammatical formatives that are not a part of the numeration, but are rather inserted during the derivation. 
place prior to PP becoming an adjunct to the $v$ P. Remember. Adjunct is a relational term: you are always an adjunct of something. Once the PP becomes an adjunct (once it is integrated into Workspace 1), the movement out it will become impossible.

Though illustrated here with a near-PP, the behavior exhibited in (13) hold, of course, of other locative PPs and this account extends to any of the examples in (18) as well as other cases of locative-PPs. ${ }^{8}$

(18) Luka je nacrtao krug ispred/iza/iznad/ispod etc. sebe/*njega. Luka AUX drew.PRT.M circle.ACC in-front-of/behind/above/below etc. oneself/him Luka drew a circle in front of/behind/above/below himself.

\subsection{Wh-extraction}

Other empirical data that illustrate that extractability - adjuncthood is relative are given in (19) and (20). As well-known, a wh-extraction from adjunct clauses is not permitted, but an extraction out a complement is allowed. Bearing this in mind, the difference between the grammaticality of (19b) and the ungrammaticality of (19d), brought about by the analysis of the post-verbal string as a single complement (included the clause) as in (20b) as opposed to the adjunct clause in (20d), is expected.

(19) a. I caught [Martin falling from the E(mpire )S(tate) B(uilding)].

b. Which building did you catch $\left[_{\text {ARGUMENT }}\right.$ Martin falling from $\left.t\right]$ ?

c. I grabbed (onto) Martin $\left[_{\mathrm{ADIUNCT}}\right.$ falling from the ESB].

d. ${ }^{*}$ Which building did you grab (onto) Martin falling from $t$ ?

(20) a. I [saw [a parcel]] [staring through the glass].

b. ${ }^{\star}$ What did you see a parcel staring through $\mathrm{t}$ ?

c. I [saw [Mary staring through the glass]].

d. What did you see Mary staring through t?

So far, we have seen that the extraction out of the PP can take place via Sideward Movement, but we have not discussed why it would take place to start with. In what follows I argue that the movement is well motivated, that the motivation is thematic and that the failure to move will result in a derivational cancellation.

\footnotetext{
${ }^{8}$ The focus of this paper is on locative PPs, but the phenomenon extends to, at least, adjuncts of cause and adjuncts of source.
} 


\section{The Nature of Thematic Roles}

\subsection{Features or Configurations?}

With the advent of Minimalism, D-structure - the locus of $\Theta$-role assignment - is eliminated. Consequently, it is not only where and how theta-roles are assigned that reopens, but crucially the nature of the thematic roles themselves. ${ }^{9}$

One school of thought, most prominently represented by Hale and Keyser (see Hale and Keyser 1999, 2002), treats them as configuration in nature. The semantic (thematic) "flavor" is to be determined by a specific position on a syntactic tree. For instance, in Harley (1995) [Spec, EventP] "reads off" as an Agents.

This line of reasoning has Baker $(1988,1997)$ 's Uniformity of Theta Assignment Hypothesis (21) as its predecessor and the work of Hale and Keyser and of those inspired by them, essentially take Baker's UTAH to its logical end by effectively making UTAH a bidirectional entailment. Namely, not only does a certain thematic flavor gets to be syntactically represented in a certain configuration, but it is the configuration that determines the exact thematic flavor.

(21) Uniformity of Theta Assignment Hypothesis (UTAH)

Identical thematic relationships between items are represented by identical structural relationships between those items at the level of D-structure

Another school of thought treats thematic roles as features on the verb (see Bošković 1994; Bošković and Takahashi 1998; Hornstein 1998, 2001; Rodrigues 2004, among others). ${ }^{10}$ Common to all featural views of thematic roles is the rejection of the traditional Theta Criterion. Whereas some of them argue that there is no one-to-one relation between a theta-role and an argument, by allowing the same argument to establish a participant relation with more than one predicate (thus carrying more than one thematic role), others argue that the same argument can establish multiple relations (carry multiple thematic roles) of the same predicate. In other words, whereas the former theories

\footnotetext{
${ }^{9}$ The question reopens only for the "mainstream" generative linguistics, where, at least since Chomsky (1981), thematic roles have been conceived as real linguistic entities and where the failure to assign/discharge/have a thematic role results in a non-convergent derivation. Jackendoff's view of thematic roles, for instance, is, of course, quite different and thematic roles are just a convenient way of thinking about the ways arguments relate to predicates and to each other.

${ }^{10}$ Just like the configuration view, the featural view of theta-roles knows many different frameworks and implementations. As the role of this section is to provide the motivation for SM, I focus only on those points that are relevant to this goal.
} 
challenge the biuniqueness of the Theta Criterion ${ }^{11}$, the latter set of theories challenges the Chain Condition as well by violating (22b).

(22) a. Given $\mathrm{CH}=\{\beta \ldots . t\}, \beta$ can function as a Case assigner or a binder

b. Given $\mathrm{CH}=\{\alpha \ldots t \mathrm{t}\}, \alpha$ is not an argument that can receive a theta-role (Chomsky 1995)

The question that arises then is if we find independent empirical evidence that challenge (22b) and show that movement into a theta position is possible. Following Bošković (1994) and Bošković and Takahashi (1998), the line of empirical research arguing that movement into the theta-position is possible and that theta roles are syntactic features in so much that they can drive movement has been argued for by many researchers (see Hornstein 1999, 2001; Manzini and Roussou 2000; Marelj 2008, to name but a few).

Here, I present an argument that shows how a long-standing puzzle of the inability of depictive to modify indirect objects in English, resolves once theta-roles can be acquired through movement. The puzzling pattern is illustrated in (23a)-(23b). Even more intriguing, Koizumi points out that the secondary predication is possible over those indirect objects that have been moved through passivization (23c).

(23) a. $I_{\mathrm{i}}$ told Martin $_{\mathrm{j}}$ the news $\mathrm{drunk}_{\mathrm{i} / \mathrm{j}_{\mathrm{j}}}$

b. I dictated Martin ${ }_{\mathrm{i}}$ the letter to $\mathrm{PRO}_{\mathrm{i}}$ read to everyone.

c. Martin ${ }_{\mathrm{i}}$ was told the news drunk

As argued by Rodrigues (2004), the most straightforward way to account for the pattern in (23c) is to abandon (22b). Namely, it seems uncontroversial that the indirect object is first merged in the complement of given, acquiring the thematic role Recipient. As it is clear from (23a), from this position, it is impossible for this complement to establish a thematic relation with the secondary predicate. This inability cannot be due to the fact that indirect objects are imperfect controllers (23b) due to their syntactic position. But only once the indirect object moves to [ Spec, TP] position, it can establish the thematic relation with the secondary predicate (23c). This clearly shows that - contra (22b) - the head of the chain can be interpreted as being in a thematic relation. ${ }^{12}$

${ }^{11}$ Since Chomsky (1986), the biuniqueness requirement has been challenged since it has been assumed that though a chain cannot have more than one theta-position, "any number of semantic roles can be assigned in this position" (Chomsky 1995: 46). Under this view, this is exactly what happens in (i).

(i) The queen painted the roses red.

${ }^{12}$ Pylkkänen (2002) offers a configuration approach to the English data like (21a), arguing that depictives can only be allowed on high-applicatives and that English indirect objects are uniformly low-applicatives. This account faces different challenges. On the one hand, Marušić 


\subsection{Motivating Sideward Movement}

Having shown that not only that carrying multiple thematic roles, but, crucially acquiring them through movement is a viable option, I move now to show how the SM can be motivated in the cases of locative PPs under consideration here. For ease of reference, I repeat, (13) as (24) here.

(24) a. Jovan je video zmiju pored sebe.

b. John saw a snake near himself.

There are 3 thematic roles to be discharged in (24); the predicate see has two thematic roles (a THEME, and PERCEIVER) and the predicate near has GROUND/THEME role that needs to be checked. There are, however, only 2 nominals present in the numeration that can check these thematic roles (23). "Consequently, "John" checks the theta role GROUND/THEME first and then moves to check the thematic role PERCEIVER. The movement leaves the trace - anaphor himself. If the thematic role PERCEVER remains unchecked, the derivation will crash. So, uncontroversially here, movement is the last resort driven by feature checking.

(25) $\mathrm{N}=\{$ John, a snake $\}$

Note, further, that my analysis also implies that an anaphor and a pronoun and are in complementary distribution here. In what follows, I sketch the derivation involving him in English and njega in SC. Contra the literature, I argue that the derivation involving the pronoun him/njega in (26), does not involve bound variable. Rather, this is a fully-fledged - phi-complete - pronoun that needs to be pulled out of the lexicon. ${ }^{13}$ Consequently, the numeration of (26) contains three, rather than two, nominals (27):

(26) a. Jovan je video zmiju pored njega.

b. John saw a snake near him.

(27) $\mathrm{N}=\{$ John, a snake, him $\}$

The predicates and consequently, the number of thematic relations remains unchanged - 3 thematic relations compared to (24). Having overviewed the basics, let us fast forward to the derivational step needed for a converging (28):

(28) a. $\left[_{\mathrm{vp}}\right.$ saw the snake] Workspace 1

b. $\left[_{\mathrm{PP}}\right.$ near $[$ him $\left.]\right]$ Workspace 2

et al. (2008) show that in Slovene, for instance, both low and high applicatives allow depictives. On the other hand, it is not obvious how this account can deal with (23c).

${ }^{13}$ As such, it is only by means of accidental coreference in Reinhart's sense (pragmatically) that 'Jovan' and 'njega' can pick out the same individual from the universe of discourse. 
The fact that there is one more nominal in the numeration guarantees that all the thematic features can be checked. Indeed, him checks the GROUND/ THEME of near and snake and Jovan check the THEME and the PERCEIVER role, respectively (29):

$\begin{array}{ll}\text { (29) a. }\left[{ }_{\mathrm{vP}} \text { [Jovan] saw the snake] }\right. & \text { Workspace } 1 \\ \text { b. }\left[{ }_{\mathrm{PP}} \text { near }[\text { him }]\right] & \text { Workspace } 2\end{array}$

Of course, there is no problem in a single nominal checking more than one thematic role. The problem here is that him, John, and snake need to get its interpretations in the sentence Hence, each of the 3 nominals must checks, at least, one thematic role. The final step in the derivation in given in (30). Two workspaces become resolved into a single workspace. Resolving the relationship between the two trees results in the PP becoming an adjunct. Merger of matrix $\mathrm{T}$ takes place and Jovan moves to [Spec, TP]:

(30) $\left[_{\mathrm{TP}}[\right.$ Jovan $] \mathrm{T}\left[_{\mathrm{vP}}\left[{ }_{\mathrm{vP}}[\right.\right.$ Jora $]$ saw a snake $]\left[_{\mathrm{PP}}\right.$ near him $\left.\left.]\right]\right]$

As argued by Marelj (2018), possessives in locative PP-adjuncts in SC behave exactly in the same way (31):

(31) Svako je nacrtao zmiju [pored svoje/*njegove noge] everyone AUx draw.PRT.M snake.ACC [near one’s/his leg] Everyone saw a snake near his leg.

\section{On Derivational Complexity and Multiple Workspaces}

\subsection{Restrictions on Sideward Movement}

Recall (section 1) that if SM could apply unchecked, it would render (4), repeated here as (32), as grammatical:

(32) ${ }^{\star}$ Who did John laugh at Bill [before Mary spoke to whe]

As argued by Hornstein (see Hornstein 2001 et seq.), the derivation crashes because two conflicting requirements need to be satisfied; "who" (Workspace 2) needs to wait until after $\mathrm{C}$ has entered the derivation before it can move, but the PP it is contained within needs to attach to the matrix structure before $\mathrm{T}$ has been merged (see (33) and (34)):

$$
\begin{array}{ll}
{\left[_ { \mathrm { CP } } \mathrm { C } \left[_ { \mathrm { TP } } [ \mathrm { John } ] \left[_{\mathrm{vP}}[\text { John] laugh at Bill]]] }\right.\right.\right.} & \text { Workspace } 1 \\
\left.\left[_{\mathrm{PP}} \text { before Mary spoke to [who }\right]\right] & \text { Workspace } 2
\end{array}
$$

(34) $\left[_{\mathrm{CP}} \mathbf{C}\left[_{\mathrm{TP}}\left[_{\mathrm{TP}}[\mathrm{John}]\left[_{\mathrm{vP}}[\mathrm{John}]\right.\right.\right.\right.$ laugh at Bill]] $\left[_{\mathrm{PP}}\right.$ before Mary spoke to [who]]]] 
The same reasoning can be applied to account for the ungrammaticality of examples like (3), repeated below as (35): ${ }^{14}$

(35) a. ${ }^{*}$ Who did Peter see the snake $\left[_{\text {Pp-adjunct }}\right.$ near-whe]?

b. ${ }^{\star}$ Pored čije je Petar video zmiju [ ${ }_{\text {Pp-adjunct }}$ pored čije noge]? next.to whose AUX Peter seen snake leg

If a $w h$-word is waiting for $\mathrm{C}$ to enter the derivation, then it will necessarily be trapped in the adjunct. As argued in Marelj (2018), the attachment site of these adjuncts is a $v \mathrm{P}$ and the target site of the $w h$-element is [Spec, $\mathrm{CP}]$. Hence, the two requirements that need to be satisfied - the requirement of the adjunct and the requirement of the wh-word are contradictory. There is no derivation that can satisfy them both.

However, if (as nowadays standardly assumed) wh-movement proceeds via the edge of the $v \mathrm{P}$ phase, that creates an escape hatch for the $w h$-phase, rendering (32) and (34) as grammatical and creating a general problem of massive overgeneration for SM.

\subsection{Timing is Everything!}

Before I explain how we can account for this, allow me to make a very short digression and present one more piece of data. Not only are the wh-LBE cases like (35b) above bad, but the pure LBE cases - where "pure" means that no other feature but $[+\mathrm{LBE}]$ is checked - seem to be even worse.

(36) ${ }^{*}$ Pored debele ${ }_{i}$ je Marko video zmiju [ $\mathrm{t}_{\mathrm{i}}$ žene] next.to fat AUX Marko see.PrT.M snake [ $\mathrm{t}$ woman]

The ungrammaticality of (36) suggests that the problem exceeds the question of $w h$-movement and the actual target position of the wh-element as the nonwh movement out of this $\mathrm{PP}$ is even worse.

Finally, note that the extraction (both wh- and the LBE) out of PP-arguments is perfectly fine.

(37) a. Jovan se oslanja na svoje/njegove $\mathrm{j}_{\mathrm{j} / \star_{\mathrm{i}}}$ prijatelje. Jovan SE rely.3Sg.Pres on one's/his friends John relies on his own friends.

b. Na čije se Jovan oslanja [načije prijatelje]?

On whose SE Jovan rely.3Sg.Pres. friends

Whose friends does Jovan rely on?

${ }^{14} \mathrm{R} 1$ brings the following example to light: Pored čije je Petar noge video zmiju? And judges it as improved compared to (35). Technically, it could be a case of extraposition (leftward movement) of an entire phrase, rather than the extraction out of it, followed by the scattered deletion, but the predictions of such an analysis are left for further research. Interestingly, what I am not sure, myself, is what the status of such examples is. It certainly requires further work and I am grateful to R1 for bringing it to my attention. 
(38) a. Jovan se suočio sa svojim/njegovim ${ }_{\mathrm{j} /{ }_{\mathrm{i}}}$ neprijateljima. Jovan SE confront.3SgPrt with one's/his enemies Jovan confronted his own enemies.

b. Sa ljutim se Jovan suočio [sa ljutim-neprijateljima]. With worst SE Jovan confront.3.Sg.Prt. enemies John confronted his own worst enemies.

This is the reason why I focus here on the status of the relevant PP, rather than on the status of the moving element. Allow me to explain. Recall that adjuncts are relational, rather than absolute notions - there is no inherent property that determines that an element is an adjunct. Rather, the property arises from the structure-building operation. Crucially, what that means is that the process of adjunction presupposes the existence of something to adjoin to - something to modify. And this simple, uncontroversial, fact is the crux of the discussion here since it begs the following question: When is the adjunction relation implemented? I argue that this must happen as soon as the adjunction site is created. In case of a $v \mathrm{P}$, this happens at the point when the $v \mathrm{P}$ is created.

For ease of exposition, the hypothesis in (5) is repeated below (39):

(39) Multiple Workspaces Earliness Hypothesis

The derivation must resolve to a single workspace at the earliest possible convenience, where "at the earliest possible convenience" means" "at the point when the adjunction site is created."

What is the rationale behind (39)? I argue that - not only the direction of (from more complex to less complex) but also the timing of syntactic computations (resolve to a single workspace as soon as possible) are guided by a more general requirement to reduce the computational complexity.

Once more, an adjunct creates an island only once it is adjoined to something. We can think of the matrix and the embedded domain as (a partially) parallel subtrees. At the point in (40), we can freely extract out of the PP simply because its status as an adjunct is not established yet. In that respect, it behaves no different that if you are extracting out of a complement PP.

a.

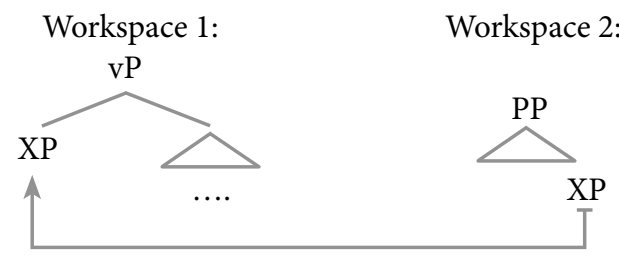

At the point where the $\mathrm{vP}$ is completed, the adjunction site exists and PP must be adjoined to it before any further operation takes place. 
b. Single workspace:

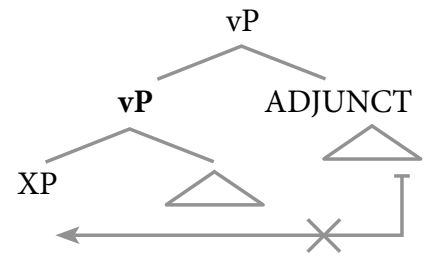

So, it is the timing of the extraction that makes a difference. The out-of the PP movement as in John saw a snake near himself happens prior to the PP becoming an adjunct because this movement is literally building the adjunction site $(v \mathrm{P})$. But once the adjunction site is build, the multiple workspaces must immediately resolve to a single (matrix) workspace resulting in the PP becoming an adjunct of the $v \mathrm{P}$. As a result, all subsequent movement out-of the PP will be barred, regardless of whether the moving element is a $w h$ - or a "pure"-LBE element. Such timing considerations do not arise in the case of a PP-complements. Once build as a separate subtree (41a), this PP merges as a sister to a head $\left(\mathrm{V}^{0}\right)$ - it is structurally an argument and following the merge of VP and $v(41 \mathrm{c})$, John moves out of the PP unimpeded.

$(41)$

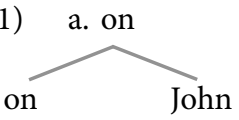

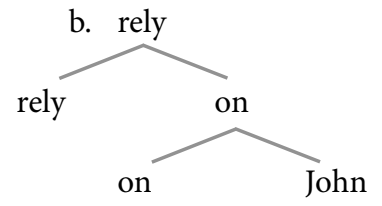

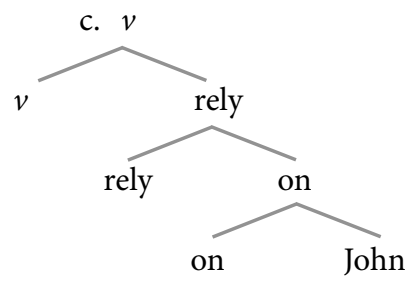

As in the previous derivations, the movement leaves an overt reflex (SELF).

(42) a. $\quad\left[_{v \mathrm{P}} \mathrm{John}{ }_{v}{ }^{0}[\mathrm{vp}\right.$ rely [on [John] SELF]]]

b. ${ }_{v \mathrm{PP}}$ John $\boldsymbol{v}^{0}\left[{ }_{\mathrm{VP}}\right.$ rely [[on SELF] ]]

As noted in Marelj (2018), the fact that the LBE out of argumental PPs is much better underscores the validity of the main argument here further.

Since it is guided by a more general requirement to reduce the computational complexity, it is the resolution of the multiple workspaces that takes precedence over movement operations out of the PP.

\section{Conclusion}

Under a derivational approach (phase-based and movement-based approaches alike), syntactic computations proceed from more complex (embedded) to less complex domains. Technically, such syntactic computations proceed via the Sideward Movement, argued further to freely apply between workspaces. Not only can SM deal elegantly with complex syntactic environments, but it also allows one to 
treat adjuncts as relational, rather than as an absolute notion. This is conceptually and empirically desirable since a given expression is only an adjunct in relation to another expression Despite its elegance, SM in not unproblematic. Though the multiple workspaces get to be resolved into a single - matrix - workspace, the issue of timing- i.e. the point in the derivation when multiple workspaces must resolve to a single derivational space has not been addressed in the literature. SM cannot really apply freely since it would - empirically incorrectly - render something like ${ }^{*}$ Who did John laugh at Bill [before Mary spoke to $t$ ] grammatical. To address such issues, I propose the Multiple Workspaces Earliness Hypothesis according to which the derivation must resolve to a single workspace at the earliest possible convenience, where "at the earliest possible convenience" means" "at the point when the adjunction site is created." I argue that - not only the direction of (from more complex to less complex) but also the timing of syntactic computations (resolve to a single workspace as soon as possible) are guided by a more general requirement to reduce the computational complexity. On the empirical side, the technical apparatus and the analysis I propose here, allow me to capture the seemingly contradictory binding facts involving locative PPs.

\section{References}

BAKER Marc Cleland (1988). Incorporation: A theory of grammatical function changing. $\mathrm{PhD}$ dissertation, MIT.

BAKER Marc Cleland (1997). Thematic roles and syntactic structure. In Elements of grammar, 73-137. Dordrecht: Springer.

BošKović Željko (1994). D-structure, Theta Criterion, and Movement into Theta-Positions. Linguistic Analysis 24, 247-287.

BošKović Željko, TaKahashi Daiko (1998). Scrambling and Last Resort. Linguistic Inquiry 29, 347-366.

BošKović Željko (2008). What will you have, DP or NP? In Proceedings of NELS 37.

Сномsку Noam (1981). Lectures on Government and Binding. Dordrecht: Foris.

Сномsкy Noam (1986). Knowledge of Language: Its Nature, Origin and Use. New York: Praeger.

Сномsкy, Noam (1995). The Minimalist Program. Cambridge, MA: MIT Press.

HaLe Kenneth, Samuel Jay Keyser (1999). Bound features, Merge, and transitivity alternations. MIT Working Papers in Linguistics, 35, 49-72.

Hale Kenneth, Samuel Jay Keyser (2002). Prolegomenon to a Theory of Argument Structure. Cambridge, MA: MIT Press.

HARLEY Heidi (1995). Subjects, Events and Licensing. PhD dissertation, MIT.

HoRNSTEIN Norbert (1998). Movement and chains, Syntax 1, 99-127.

HoRnstein Norbert (2001). Move! A Minimalist Theory of Construal. Oxford: Blackwell. Hornstein Norbert (2006). Pronouns in a Minimalist Setting. In University of Maryland Working Papers in Linguistics 14. Nina KaZanina et al. (eds.), 47-80. College Park, MD: UMWPiL. 
HuAng James (1982). Logical Relations in Chinese and the Theory of Grammar. Cambridge, PhD dissertation, MIT.

KoIzumi Masatoshi (1993). Object Agreement Phrase and the Split VP Hypothesis. In Papers on Case and Agreement I. MIT Working Papers in Linguistics, 18. Jonathan David BOBALJIK, Collin PHILIPS (eds.), 25-79. Cambridge, Mass.: MIT Press.

Manzini Rita, Roussou Anna (2000). A Minimalist Approach to A-Movement and Control, Lingua 110, 409-447.

Marelj Marijana (2008). A Left Branch Extraction Perspective on Bound Variables and Pronoun Insertion Strategy, NELS 37, 73-87.

Marelj Marijana (2010). Bound-Variable Anaphora and Left Branch Condition, Syn$\operatorname{tax} 14,205-229$.

Marelj Marijana (2018). When Near Snakes Move Sideward! In Formal Approaches to Slavic Linguistics: The Third Cornell Meeting 2016. Wayles Browne, Miloje Despić, Naomi Enzinna, Simone Harmath-de Lemos, Robin Karlin, Draga Zec (eds.), 140-159. Ann Arbor: Michigen Slavic Publications.

MARUšIČ Franc, MARvin Tatjana, ŽAUCER Rok (2008). Depictive secondary predication with no PRO. In Formal description of Slavic languages: The fifth conference Leipzig 2003. Zyватоw Gerhild (ed.), 423-434. Frankfurt am Main: Peter Lang.

Nunes, Jairo (1995). The Copy Theory of Movement and Linearization of Chains in the Minimalist Program. PhD dissertation, University of Maryland at College Park.

Nunes Jairo (2001). Sideward movement, Linguistic Inquiry 32, 303-344.

Progovac Ljiljana (2005). A Syntax of Serbian Clausal Architecture. Bloomington, IN: Slavica Publishers.

Pylkkänen, Liina. 2002. Introducing Arguments. PhD dissertation, MIT.

ReInHART Tanya (1983). Anaphora and semantic interpretation. London: Croom-Helm.

ReInhart Tanya, Reuland Eric (1991). Anaphors and logophors: an argument structure perspective. In Long-distance Anaphora. Jan Koster, Eric Reuland (eds.), 281-321. Cambridge: Cambridge University Press.

ReInhart Tanya, Reuland Eric (1993). Reflexivity, Linguistic Inquiry 24, 657-672.

Rodrigues Celina (2004). Thematic Chains, D.E.L.T.A., 20/1, 123-147.

Ross John Robert (1967). Constraints on Variables in Syntax. Cambridge, MA: PhD dissertation, MIT.

STEPANOv Arthur (2007). The end of CED? Minimalism and extraction domains, Syn$\operatorname{tax} 10,80-126$.

TALIĆ Aida (2013). Extraordinary complement extraction: PP-complements and inherently case-marked nominal complements, Studies in Polish Linguistics 8, 127-150.

Truswell Robert (2011), Events, Phrases, and Questions. Oxford: Oxford University Press.

Uriagareka Juan (1999). Multiple Spell-out. In Working Minimalism, Samuel EpSTEIn, Norbert HoRnstein (eds.), 251-282. Cambridge, MA: MIT Press.

Marijana Marelj

UiL OTS, Utrecht University

Trans 10, 3512 JK

Utrecht

The Netherlands 